\title{
Haematological Responses and Nutrient Utilization of Clarias gariepinus Fed Fermented Groundnut Shell Diets
}

\section{Michael ET*, Amos SO, Hassan GT and Bukar MA \\ Department of Fisheries, Modibbo Adama University of Technology, Yola, Nigeria}

*Corresponding author: Ekundayo Taiye Michael, Department of Fisheries, Modibbo Adama University of Technology, Yola, Nigeria, Tel: +2347061291539; Email: taiyemichael@gmail.com

\section{Research Article \\ Volume 3 Issue 3}

Received Date: August 04, 2019

Published Date: August 23, 2019

DOI: $10.23880 /$ ijoac- 16000171

\section{Abstract}

This research study was carried out to evaluate the use of fermented groundnut shell diet on growth performance and haematological parameters of Clarias gariepinus fingerlings. Semi flow through consist of fifteen plastic bowls were used and ten Clarias gariepinus fingerlings (mean weight $(3.00 \pm 0.05 \mathrm{~g}$ ) per plastic bowl, each in triplicate. Five treatment bowls were fed experimental diets containing $40.00 \%$ crude protein supplemented with fermented groundnut shells. Diet 1 contain unfermented groundnut shell (control diet), diet 2 contain 12 hours fermented groundnut shell without potash, while the other diets, diet 3,4 , and 5 contain fermented groundnut shells with potash at fermentation time of 12,24 , and 48 hours respectively. The highest mean weight gain (MWG) of $5.87 \mathrm{~g}$, and specific growth rate (SGR), $0.51 \% /$ day was recorded in diet 5 . The best feed conversion ratio (FCR) was also recorded in fish fed diet $5(0.43)$. There was significant difference $(p<0.05)$ in MWG, SGR, and FCR among the treatments. Results showed that fish fed diet 5 had the best growth performance. Weight gain by fish fed diet 1 (control diet) and diet 5 were not statistically different $(p<0.05)$. But there was statistical difference in among the diets in specific growth rate, feed conversion ratio, and protein efficiency ratio. Results showed that there were increase in the blood parameters of Clarias gariepinus fermented diets compared to the control diet but were statistically different ( $\mathrm{p}<0.05$ ). Highest Packed cell volume of $22.23 \%$, White Blood Cell, $15.50 \times 10^{3}$, red blood cell $9.35 \times 10^{6}$ and Haemoglobin, $10.35 \mathrm{~g} / \mathrm{dl}$ were recorded in fish fed diet 5. All blood parameters obtained were between the range of recommended fish blood. It is concluded that using fermented groundnut shell as supplementary feed on Clarias gariepinus showed a slight increase in the haematological parameters compared with the control diet but it has no negative effect on the health status of the studied fish. However, diet 5 can be used as feed in aquaculture, to enhance fish health, survival and growth performance.

Keywords: Haematology; Clarias gariepinus; Growth performance; Solid state fermentation; Potash; Groundnut shell 


\section{International Journal of Oceanography \& Aquaculture}

\section{Introduction}

The main goals of aquaculture industry are to optimize growth and to produce high quality fish [1]. With the rise in global awareness of fish as a valuable source of protein, this has led to increased progress in aqua feeds with diets being specifically designed to meet the nutritional requirements of species, life cycle and health condition of fish [2].

The use of haematological characteristics in evaluating the health status of fish as a tool for its management under captive rearing is well established and the knowledge of the haematological profile of a fish also indicates its dietary sufficiency and physiological response to environmental stress and any change in the constituent component of blood sample when compared to the normal values could be used to interpret the metabolic state of the animal and the influence of treatment given to the animal [3-5].

Similarly, Babatunde, et al. [6] also reported that any changes in the constituent component of blood sample when compared to the normal values could be used to interpret the metabolic state of animal and state of health. Low haematological indices are indications of anaemic conditions [7].

Blood tissue truly reflects physical and chemical changes occurring in organisms. Therefore, detailed information can be obtained on general metabolism and physiological status of fish in different groups of age and habitat. Early diagnosis is also possible when evaluating haematological data [8-10]. Furthermore, it should be noted that haematological indices are of different sensitivity to various environmental factors and chemicals, previous haematological study of nutritional effects, infectious diseases and pollutants, brought knowledge that erythrocytes are the major and reliable indicators of various sources of stress [11-15].

Groundnut (Arachis hypogea) shell is a by-product of groundnut processing industry. In Nigeria, and many other neighbouring countries, in addition to industrial extraction of oil, groundnut is consumed directly as nut fresh, dry or cooked. It is also grown as cash crop for exporting. Groundnut shell is a waste produced when the nut is being processed for consumption by breaking the shell open manually or mechanically.

The proximate compositions of groundnut shells as feedstuff for livestock have been documented. Alu, et al.
[16] reported the nutrient composition of untreated and potash treated groundnut shells to be $96.11 \%$ dry matter, $13.88 \%$ crude protein, $37.82 \%$ crude fibre, $1.87 \%$ ether extract, $4.30 \%$ ash, and $56.04 \%$ nitrogen free extract for the untreated groundnut shells. The chemical composition for the potash treated groundnut shells were $85.59 \%$ dry matter, $12.07 \%$ crude protein, $10.26 \%$ crude fibre, crude lipid $1.79 \%, 4.12 \%$ ash and $51.34 \%$ nitrogen free extract [16].

Groundnut shells are classified as low value agricultural wastes or agricultural by-products. However, new technology and innovation has converted groundnut shells to a wide range of applications. Groundnut shells which are agricultural by-products are one of the most available biomass resources in northern part of Nigeria. This unique renewable energy resource has a high potential to be an alternative for fish feed. The presence of lignin in these agrowastes limit their utilization by either herbivorous or omnivorous fish, hence there is a need to break this lignin barrier either by physical, chemical or/and biological treatments. The biological treatment such as solid state fermentation of fibrous materials is not entirely new and the biotechnological techniques are gradually being introduced into the field of aquaculture nutrition/biotechnology nutrition throughout the globe. If the huge amount could be recycled or converted to useful feedstuff, the whole environment will be cleaned of pollution, thereby improving human health [17].

Over the years, fish farmers have depended on agrowastes and industrial by-products as sources of feed for their fish. But, the use of these 'wastes' as unconventional feedstuff for fish nutrition is largely limited by their high cell wall material content including lignin, cellulose and hemicellulose [18].

Production of groundnut wastes such as the shell has becomes a serious issue to environment in Yola, Adamawa state and Nigeria as a whole. The common methods in handling oilseed harvest residues such as groundnut by-products are incineration, incorporation in soil and land dumping. However, incineration will emit smokes or particulates which cause air pollutions; incorporation of agricultural waste in soil will influence physical, biological and chemical properties of soil [19]. These methods are not the good solutions in managing tremendous amount of groundnut by-products. Thus, this poses a critical problem in waste management system and subsequently causes environmental pollution if the agro waste is not managed properly [20]. 


\section{International Journal of Oceanography \& Aquaculture}

Another limitation with the use of these 'wastes' as feed for fish is the presence of anti-nutritional factors (ANFs). The presence of anti-nutritional factors such as phytic acid, lectins, saponins, alkaloids, gluconosilates, phyto-estrogens and other anti-vitamins in plant-based feeds such groundnut shell limits its usage in animal feedstuffs as well as aquaculture feeds [21]. Nutritionists believe that anti-nutritional factors responsible to influence physiological characteristic and retard growth of animals [22]. Anti-nutritional factors are naturallyoccurring compounds that exert anti-nutritional effect, anti-physiological effect and limit the nutrients availability to living organism $[23,24]$.

Utilization of groundnut shell as fish feedstuffs can offers several benefits. First and foremost, it is cost-saving compared to conventional feedstuffs [22]. Conventional feedstuffs such as fish, crustacean and animal meal are relatively expensive than plant-based feedstuffs [25]. Sharp rises of animal feed market prices has encouraged fish farmers to seek cost-saving alternatives, which is byproducts from oilseed or legumes [26].

The pre-treatment of agro-wastes is necessary to improve and maximize fish utilization of agro-wastebased diets. Besides physical pre-treatment methods such as size reduction, chemical treatment of 'agro-wastes' has been met with insignificant improvement of digestibility problems [27]. Because of the high cost of chemicals, and the laborious processes of using them, none of the chemical treatments known to remove considerable amounts of tannins and other anti-nutrients have been suggested to be economically friendly [28]. However, the use of biological pre-treatments such as solid state fermentation methods to ameliorate nutritional values of fibrous materials like groundnut shell for fish is an area that is worth to be explored. And its effect on the blood parameters of Clarias gariepinus fingerlings is also investigated in this study.

\section{Materials and Methods}

\section{Experimental Site}

The experiment was carried out in the Teaching and Research Fish Farm, Department of Fisheries, Modibbo Adama University of Technology, Yola, Nigeria. Five experiment sets in triplicate were used for this experiment. The experimental set-up which is semi-flow through system consisted of fifteen (15) circular plastic tanks. The semi-flow through consist of inlet pipe through which water is supplied to the set-up, outlet pipe through which regulate water inflow to the set-up, plastic bowls that serve as aquatic environment for the experimental fish fingerlings and net which prevent fingerlings from jumping out. The plastic tanks were cleaned, disinfected and allowed to dry for 24 hours, after which water was supplied to two-third of the size of the tank and were covered with net of mesh size $3 \mathrm{~mm}$ to protect the fish from jumping out of the tanks. The experiment lasted for a period of 12 weeks.

\section{Dietary Ingredients}

The dietary ingredients for the diet formulation comprised of $5 \mathrm{~kg}$ weight of groundnut shells which were obtained from groundnut processing firm in Yola town; other ingredients consisted of fish meal, groundnut cake, vitamin premix, cassava starch, salt, palm oil, methionine, and lysine were bought from Jimeta main market, Yola.

\section{Processing of Groundnut Shells}

The groundnut shells were rinsed with distilled water to remove debris and pretreated using oven heat treatment at $100^{\circ} \mathrm{C}$ until a constant weight was obtained for any dry matter. This was to obtain constant dryness and to prevent groundnut shells from being infected with fungi such as aflatoxin before solid state fermentation process. Solid state fermentation was carried out in controlled laboratory under room temperature. The oven dried groundnut shells were given six different treatments of solid state fermentation for a period of 0 , 12,24 , and 48 hours in accordance with Sogbesan, et al. [17] where $100 \mathrm{ml}$ of distilled water and $10 \mathrm{~g}$ of potash were added to $500 \mathrm{~g}$ groundnut shells. The addition of potash is to serve as softening agent and to serve as buffer in order to create a suitable medium for the growth of fungi [29]:

(a) Control: $500 \mathrm{~g}$ of raw cleaned dried groundnut shells were not subjected to solid state fermentation thereby serving as control.

(b) Moistened without ash for 12 hours (S12): $500 \mathrm{~g}$ Groundnut shells were moistened with $100 \mathrm{ml}$ distilled water only and fermented for 12 hours under laboratory conditions.

(c) Moistened with ash for 12 hours (SA12): $500 \mathrm{~g}$ Groundnut shells were moistened with $100 \mathrm{ml}$ distilled water and $10 \mathrm{~g}$ of potash; fermented for 12 hours under laboratory conditions.

(d) Moistened without ash for 24 hours (S24): $500 \mathrm{~g}$ Groundnut shells were moistened with $100 \mathrm{ml}$ distilled water only and fermented for 24 hours under laboratory conditions. 


\section{International Journal of Oceanography \& Aquaculture}

(e) Moistened with ash for 24 hours (SA24): $500 \mathrm{~g}$ Groundnut shells were moistened with $100 \mathrm{ml}$ distilled water and $10 \mathrm{~g}$ of potash; fermented for 24 hours under laboratory conditions.

(f)Moistened without ash for 48 hours (S48): $500 \mathrm{~g}$ Groundnut shells were moistened with $100 \mathrm{ml}$ distilled water only and fermented for 48 hours under laboratory conditions.

(g) Moistened with ash for 48 hours (SA48): Groundnut shells were moistened with $100 \mathrm{ml}$ distilled water and $10 \mathrm{~g}$ of potash; fermented for 48 hours under laboratory conditions.

\section{Milling of Solid State Fermented Groundnut Shells}

The solid state fermented groundnut shells were oven dried at the end of each fermentation time of 12 hours, 24 hours and 48 hours respectively at a temperature of $100^{\circ} \mathrm{C}$ for 12 hours and followed by grinding using hammer mill grinding machine to a powdery form. They were sieved and kept for further use in the formulation of fish feed with other ingredients.

\section{Formulation of Experimental Diets}

Five isonitrogenous diets were formulated based on the proximate analysis from practical ingredients such as milled fermented groundnut shells, fish meal, groundnut cake, vitamin premix, cassava starch, salt, palm oil, methionine, and lysine. The control basal diet supplemented with maize meal was without fermented groundnut shell meal and others were supplemented with fermented groundnut shell meal at 12, 24 and 48 hours respectively. The experimental diets were formulated to contain $40 \%$ crude proteins. The ingredients were milled to give a fine particle size. And they were thoroughly mixed to obtain a homogenous mass, cassava starch was added as binder. The resultant mash was then pressed without steam through a pelleting machine with $0.2 \mathrm{~mm}$ diameter size. The pellets were sun dried at ambient temperature $\left(27-30^{\circ} \mathrm{C}\right)$ and stored in a refrigerator until the commencement of the experiment.

\section{Sampling and Monitoring of the Experimental Fish}

The length and weight of each fingerling in each tank was measured at the commencement of the experiment. Afterward, 5 fingerlings were randomly taken from each tank once a week and weighed with sensitive weighing balance to access the growth rate. The sampling exercises were carried out in the morning before feeding the fish.
Any dead fish is quickly removed and recorded to determine the survival rate. The experiment lasted for 12 weeks.

\section{Water Quality}

The water quality parameters were monitored and average value for temperature; dissolved oxygen and hydrogen ion concentration $(\mathrm{pH})$ were $28.86 \pm 0.04^{\circ} \mathrm{C}$, $6.34 \pm 0.01 \mathrm{mg} / \mathrm{L}$ and 7.17 units respectively.

\section{Proximate Analysis}

Fish carcass and experimental diets were proximately analyzed for crude protein, crude fibre, crude lipid, ash and Nitrogen free extracts according to Association of Official Analytical Chemist Methods [30].

\section{Transportation and Acclimatization of Experimental Fish}

One hundred and fifty fingerlings of C. gariepinus were obtained from Salihu farm in Yola and transported to the laboratory in 50 litre water storage can. They were held in circular plastic tanks for one week for acclimation. They were also randomly stocked at the rate of ten (10) fingerlings per plastic bowl in triplicate into 15 plastic bowls for growth trials. They were aerated with electric powered aerator. All fishes were considered healthy on the basis of their appearance and the absence of obvious signs of disease.

\section{Growth Performance and Nutrient Utilization}

Growth performance was expressed as weight gain, relative weight gain, specific growth rate, metabolic growth rate, condition factors and survival rate [31,32]. Feed utilization indices were expressed as feed conversion ratio, protein efficiency ratio and protein rating as follows $[33,34]$ :

$$
\begin{aligned}
& \text { Mean weight gain }=\frac{\mathrm{W}_{\mathrm{f}}-\mathrm{W}_{\mathrm{i}}}{\mathrm{n}} \\
& \text { Relative growth rate }=\frac{\text { Weight gain }}{\text { Initial body weight }} \times 100 \\
& \text { Specific growth rate }(\mathrm{SGR})=\frac{\operatorname{LogW}_{\mathrm{f}}-\log \mathrm{W}_{\mathrm{i}}}{\mathrm{t}} \times 100
\end{aligned}
$$

Metabolic growth rate $=$

Live body weight gain

$\frac{\left\{\left(\mathrm{W}_{\mathrm{i}}+\mathrm{W}_{\mathrm{f}}\right)\right\}^{0.8}}{2000}$

Experimental period (days) 


\section{International Journal of Oceanography \& Aquaculture}

$$
\begin{aligned}
\text { Condition factor, } \mathrm{k} & =\frac{100 \mathrm{~W}}{\mathrm{l}^{3}} \\
\text { Survival rate, SR }(\%) & =\frac{\mathrm{N}_{\mathrm{f}} \times 100}{\mathrm{~N}_{\mathrm{i}}} \\
\text { Feed conversion ratio, FCR } & =\frac{\text { Weight gain }(\mathrm{g})}{\text { Feed intake }(\mathrm{g})}
\end{aligned}
$$

Protein intake, PI (g of protein in $100 \mathrm{~g}$ diet/fish) = Total feed intake $\mathrm{x} \%$ crude protein in the diet.

Protein efficiency ratio, PER =

Mean weight gain $(\mathrm{g})$

Mean protein intake ( $\mathrm{g}$ of protein in $100 \mathrm{~g}$ of diet / fish)

$$
\text { Net protein utilization, } \mathrm{NPU}=\frac{\mathrm{CP}_{\mathrm{f}-\mathrm{CP}_{\mathrm{i}}}}{\mathrm{PI}}
$$

\section{Haematological Profile}

Blood was collected from the caudal vein of each fish using heparinized disposable syringes and hypodemic needles at the beginning and end of the experimental period. Red blood cells (RBC) White Blood cells (WBC) hemoglobin (Hb), packed cell volume (PCV) and leukocyte differential were analyzed according to Schalm, et al. [35]. The PCV was analyzed using micro haematocrit method; haemoglobin concentration was also determined by Schalm, et al. [35]. Erythrocyte indices of Mean Corpuscular Volume (MCV), Mean Corpuscular Haemoglobin (MCH) and Mean Corpuscular Haemoglobin Concentration (MCHC) were determined using the formula of Schalm, et al. as follows [35]:

$$
\begin{gathered}
\mathrm{MCV}=\frac{\mathrm{PCV} \times 10(\text { fentolitre })}{\mathrm{RBC}} \\
\mathrm{MCH}=\frac{\mathrm{Hb} \times 10(\text { fentolitre })}{\mathrm{RBC}} \\
\mathrm{MCHC}=\frac{\mathrm{Hb} \times 100 \%}{\mathrm{PCV}}
\end{gathered}
$$

\section{Statistical Analysis}

All data collected were subjected to analysis of variance (ANOVA). Comparisons among treatment means were carried out by one way analysis of variance followed by Turkey's test (0.05). Least significance differences (LSD) was used to determine the level of significance among treatments. Correlation and regression analysis was carried out to determine the relationship between the treatments using SPSS 10.0 Window 2000.

\begin{tabular}{|c|c|c|c|c|c|}
\hline Ingredients (g/kg) & Diet 1 & Diet 2 & Diet 3 & Diet 4 & Diet 5 \\
\hline Fish Meal & 30 & 30 & 30 & 30 & 30 \\
\hline Maize & 30 & 0 & 0 & 0 & 0 \\
\hline Fermented Groundnut shell & 34 & 34 & 34 & 34 & 34 \\
\hline Groundnut cake & 0 & 30 & 30 & 30 & 30 \\
\hline Vitamin Premix & 2 & 2 & 2 & 2 & 2 \\
\hline Starch & 1 & 1 & 1 & 1 & 1 \\
\hline Salt & 0.5 & 0.5 & 0.5 & 0.5 & 0.5 \\
\hline Palm-Oil & 0.5 & 0.5 & 0.5 & 0.5 & 0.5 \\
\hline Methionine & 1 & 1 & 1 & 1 & 1 \\
\hline Lysine & 1 & 1 & 1 & 1 & 1 \\
\hline Total & 100 & 100 & 100 & 100 & 100 \\
\hline Calculated Crude Protein (\%) & 40.02 & 40.02 & 40.02 & 40.02 & 40.02 \\
\hline Calculated gross energy (kcal/100g) & 12.07 & 12.07 & 12.07 & 12.07 & 12.07 \\
\hline Protein/Energy ratio & 3.32 & 3.32 & 3.32 & 3.32 & 3.32 \\
\hline
\end{tabular}

Table 1: Formulation and Composition of Experimental Diets.

Keys: Control=Diet 1; Diet 2 (S12), Diet 3 (SA12), Diet 4 (SA24) and SA48 (Diet 5). 


\section{International Journal of Oceanography \& Aquaculture}

\begin{tabular}{|c|c|c|c|c|c|c|}
\hline Proximate Analysis & Diet 1 & Diet 2 & Diet 3 & Diet 4 & Diet 5 & SEM \\
\hline Crude Protein & 41.61 & 42.51 & 42.77 & 43.28 & 43.41 & 0.32 \\
\hline Ether Extract & 9.3 & 8.51 & 7.2 & 7.22 & 7.15 & 0.44 \\
\hline Crude fibre & 3.31 & 2.15 & 1.1 & 1.14 & 1.08 & 0.44 \\
\hline Ash & 4 & 4.51 & 4.72 & 4.81 & 4.85 & 0.16 \\
\hline Dry matter & 86.89 & 86.8 & 87.75 & 87.7 & 88.03 & 0.25 \\
\hline Nitrogen free extract (NFE) & 28.67 & 29.12 & 31.96 & 31.25 & 31.54 & 0.67 \\
\hline Calculated Gross Energy (kcal/100g) & 1842.47 & 1840.25 & 1843.48 & 1844.1 & 1849.39 & 1.26 \\
\hline
\end{tabular}

Table 2: Proximate Composition of Experimental Diets (g/100g).

NB: Calculated gross energy = Protein X 23.6KJ/100g + Lipid X $39.5 \mathrm{KJ} / 100 \mathrm{~g}+\mathrm{NFE} \mathrm{X} \mathrm{17.2KJ/100g.}$

\begin{tabular}{|c|c|c|c|c|c|c|}
\hline $\begin{array}{c}\text { Component } \\
\text { (\%) }\end{array}$ & $\begin{array}{c}\text { Initial } \\
\text { Fish }\end{array}$ & $\begin{array}{c}\text { Fish fed diet 1 } \\
\text { (Control) }\end{array}$ & $\begin{array}{c}\text { Fish fed diet 2 } \\
\text { (S12) }\end{array}$ & $\begin{array}{c}\text { Fish fed diet 3 } \\
\text { (SA12) }\end{array}$ & $\begin{array}{c}\text { Fish fed diet 4 } \\
\text { (SA24) }\end{array}$ & $\begin{array}{c}\text { Fish fed diet 5 } \\
\text { (SA48) }\end{array}$ \\
\hline Moisture & 4.15 & 4.1 & 3.65 & 3.7 & 4.05 & 4.11 \\
\hline Crude protein & 61.38 & 63.3 & 65.1 & 67.15 & 68.05 & 68.9 \\
\hline Crude lipid & 9.6 & 8.96 & 9.55 & 9.6 & 10.4 & 9.58 \\
\hline Ash & 5.51 & 5.3 & 5.2 & 3.8 & 3.05 & 3.95 \\
\hline Crude fibre & 2.1 & 2.15 & 2.12 & 1.94 & 1.73 & 1.82 \\
\hline NFE & 17.26 & 17.24 & 17.23 & 17.01 & 17.02 & 16.14 \\
\hline
\end{tabular}

Table 3: Proximate Carcass Composition of Clarias gariepinus fed Fermented Groundnut Shell Diet at the beginning and end of the Feeding Trial.

\begin{tabular}{|c|c|c|c|c|c|c|}
\hline Parameter & $\begin{array}{c}\text { Diet 1 } \\
\text { (Control) }\end{array}$ & Diet 2 (S12) & $\begin{array}{c}\text { Diet 3 } \\
\text { (SA12) }\end{array}$ & Diet 4 (SA24)Diet 5 (SA48) & SEM \\
\hline Initial mean weight (g) & 3 & 3.22 & 3.65 & 3.6 & 3.5 & 0.12 \\
\hline Final mean weight (g) & 7.96 & 7.8 & 9 & 7.44 & 9.37 & 0.37 \\
\hline Mean weight gain (g/fish) & $4.96 \pm 0.02 \mathrm{a}$ & $4.58 \pm 0.05 \mathrm{ab}$ & $5.35 \pm 0.04 \mathrm{ac}$ & $3.84 \pm 0.02 \mathrm{ad}$ & $5.87 \pm 0.01 \mathrm{a}$ & 0.34 \\
\hline Relative growth rate (\%/fish) & 165 & 142 & 147 & 107 & 168 & 10.92 \\
\hline Metabolic growth rate & 17.42 & 15.99 & 16.72 & 13.37 & 18.1 & 0.82 \\
\hline Specific growth rate (\%/day) & $0.50 \pm 0.00 \mathrm{a}$ & $0.46 \pm 0.01 \mathrm{~b}$ & $0.47 \pm 0.01 \mathrm{~b}$ & $0.38 \pm 0.02 \mathrm{a}$ & $0.51 \pm 0.00 \mathrm{ab}$ & 0.02 \\
\hline Mean feed intake (g) & $2.56 \pm 0.01 \mathrm{a}$ & $2.60 \pm 0.01 \mathrm{ac}$ & $2.53 \pm 0.00 \mathrm{ad}$ & $2.54 \pm 0.01 \mathrm{ad}$ & $2.51 \pm 0.01 \mathrm{bd}$ & 0.02 \\
\hline Feed conversion rate(FCR) & $0.52 \pm 0.01 \mathrm{a}$ & $0.57 \pm 0.01 \mathrm{a}$ & $0.47 \pm 0.01 \mathrm{bc}$ & $0.66 \pm 0.01 \mathrm{ac}$ & $0.43 \pm 0.01 \mathrm{bd}$ & 0.04 \\
\hline Survival (\%) & 87 & 83 & 93 & 87 & 80 & 2.19 \\
\hline Protein intake & 10.75 & 10.92 & 10.63 & 10.67 & 10.54 & 0.06 \\
\hline Protein efficiency ratio (PER) & $0.46 \pm 0.02 \mathrm{a}$ & $0.42 \pm 0.01 \mathrm{ac}$ & $0.50 \pm 0.01 \mathrm{ac}$ & $0.36 \pm 0.02 \mathrm{bc}$ & $0.56 \pm 0.02 \mathrm{ac}$ & 0.03 \\
\hline Protein rating & 4.95 & 4.59 & 5.32 & 3.84 & 5.9 & 0.35 \\
\hline Condition factor (k) & 2.17 & 2.54 & 1.86 & 3.63 & 1.55 & 0.36 \\
\hline Net Protein Utilization (NPU) & 0.18 & 0.34 & 0.54 & 0.63 & 0.71 & 0.09 \\
\hline
\end{tabular}

Table 4: Growth Parameters and Feed Utilization Indices of Clarias gariepinus fingerlings fed Fermented Groundnut Shell Diets.

NB: Values with same superscript along row are statistically not different to each other and vice versa. 


\section{International Journal of Oceanography \& Aquaculture}

\begin{tabular}{|c|c|c|c|c|c|c|}
\hline Parameter & Diet 1 (Control) & Diet 2 S12 & Diet 3 SA12 & Diet 4 SA24 & Diet 5 SA48 & SEM \\
\hline PCV (\%) & $21.50 \mathrm{a}$ & $19.10 \mathrm{~b}$ & $22.15 \mathrm{a}$ & $22.23 \mathrm{a}$ & $22.65 \mathrm{a}$ & 0.64 \\
\hline WBC (x 103) & $13.25 \mathrm{a}$ & $12.30 \mathrm{a}$ & $13.37 \mathrm{a}$ & $15.50 \mathrm{~b}$ & $15.65 \mathrm{~b}$ & 0.66 \\
\hline $\mathrm{RBC}(\mathrm{x} 106)$ & $9.10 \mathrm{a}$ & $8.25 \mathrm{~b}$ & $9.22 \mathrm{a}$ & $9.35 \mathrm{a}$ & $10.04 \mathrm{a}$ & 0.29 \\
\hline $\mathrm{Hb}(\mathrm{g} / \mathrm{dL})$ & $10.25 \mathrm{a}$ & $10.04 \mathrm{a}$ & $10.13 \mathrm{a}$ & $10.30 \mathrm{a}$ & $10.55 \mathrm{a}$ & 0.09 \\
\hline $\mathrm{MCV}(\mathrm{fL})$ & $23.63 \mathrm{a}$ & $23.15 \mathrm{a}$ & $24.02 \mathrm{a}$ & $23.78 \mathrm{a}$ & $22.56 \mathrm{~b}$ & 0.26 \\
\hline MCH (pg) & $11.26 \mathrm{a}$ & $12.17 \mathrm{~b}$ & $10.99 \mathrm{a}$ & $11.02 \mathrm{a}$ & $10.51 \mathrm{a}$ & 0.27 \\
\hline MCHC (g/dL) & $47.67 \mathrm{a}$ & $52.57 \mathrm{~b}$ & $45.73 \mathrm{a}$ & $46.33 \mathrm{a}$ & $46.58 \mathrm{a}$ & 1.24 \\
\hline Blood Glucose (mg/dL) & $43.29 \mathrm{a}$ & $41.13 \mathrm{~b}$ & $37.23 \mathrm{c}$ & $37.81 \mathrm{c}$ & $33.33 \mathrm{c}$ & 1.71 \\
\hline
\end{tabular}

Table 5: Haematological parameters of Clarias gariepinus fingerlings fed fermented groundnut shell meal.

Keys: $\mathrm{PCV}=$ Packed cell volume, $\mathrm{WBC}=$ White blood cell, $\mathrm{RBC}=\mathrm{Red}$ blood cell, $\mathrm{Hb}=$ Haemoglobin, $\mathrm{MCV}=$ Mean corpuscular volume, $\mathrm{MCH}=$ Mean corpuscular haemoglobin, $\mathrm{MCHC}=$ Mean corpuscular haemoglobin concentration.

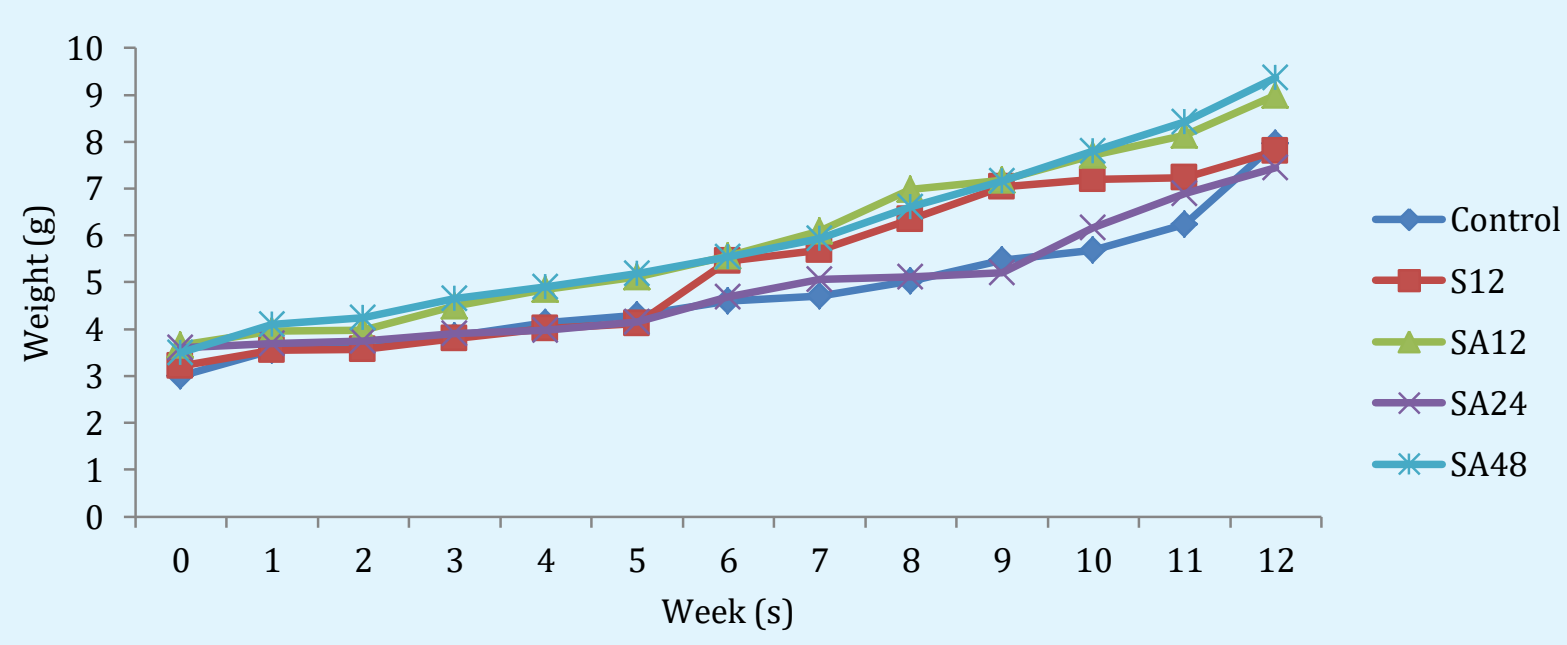

Figure 1: Weekly growth pattern of Clarias gariepinus fed fermented groundnut shell diet for 12 weeks.

\section{Results}

\section{Proximate Composition of Experimental Diets}

The proximate composition of the experimental diets is presented in Table II. The highest crude protein of $43.41 \%$ was recorded in diet 5 while the lowest crude protein was in diet 1 . Ether extract was highest in diet 1 with $9.30 \%$ composition and the lowest ether extract was recorded with the value of $7.15 \%$ in diet 5 . The crude fibre of $3.31 \%$ was the highest in diet 1 while $1.08 \%$ value is the lowest in diet 5 . The gross energy values range from 1842.47 to $1849.39 \mathrm{KJ} / 100 \mathrm{~g}$ for diet 1 and diet 5 respectively. The gross energy values increases as the fermentation time increases from diet 1 to diet 5 .

\section{Chemical Composition of the Carcass of Clarias gariepinus after 12 Weeks of Feeding Fermented Groundnut Shell Meal Diets}

Proximate analysis of the whole fish body at the end of the 12 weeks experimental period is summarized Table III. These data indicated that moisture content $(4.11 \%)$ was highest in the fish fed diet 5 while the lowest moisture content was in the fish fed diet 2 with the value of $3.65 \%$. Highest crude protein $68.90 \%$ composition was recorded for fish fed diet 5 and $61.38 \%$ being the lowest value in the initial fish. $10.40 \%$ of ether extract composition was noted for fish fed diet 4 and fish fed diet 1 had $8.90 \%$ of ether extract. The crude fibre for the fish fed experimental diets range from $1.73 \%$ to $2.15 \%$. The 


\section{International Journal of Oceanography \& Aquaculture}

highest value of $2.15 \%$ was obtained in fish fed diet 1 and the lowest value of $1.73 \%$ was recorded in fish fed diet 4 .

\section{Growth Performance and Nutrient Utilization of Clarias gariepinus Fingerlings Fed with Experimental Diets}

The growth response of Clarias gariepinus fed with experimental diets is shown in Table IV. The results showed that the highest mean weight gain was achieved with the fish fed diet 5 and the lowest mean weight gain was recorded for diet 4 with the value of $5.87 \mathrm{~g}$ and $3.84 \mathrm{~g}$ respectively. Diet 1 and diet 5 are not statistically different to each other; while there is statistical difference among diet 2, 3, and 4 at $\mathrm{p}<0.05$. Similarly, the highest specific growth rate (SGR) (0.51\%/day), metabolic growth rate (18.10), protein efficiency ratio (PER) (0.56), and net protein utilization (NPU) (0.71), were recorded in diet 5 and the lowest SGR (0.38\%/day), MGR (13.37), PER $(0.36)$ and NPU (0.18) were from fish fed diet 4 . The best feed conversion ratio (FCR) of 0.43 was recorded in treatment diet 5. All the parameters studied were significantly different $(\mathrm{p}<0.05)$ among each other and the control diet (diet 1). Figure 1 presented the growth pattern and it showed a linear growth pattern among the fish fed fermented groundnut shell diets and the control diet (diet 1). The highest survival rate of $93 \%$ was recorded in diet 3 and the lowest of $80 \%$ was in diet 5 .

\section{Haematological Parameters of Clarias gariepinus Fingerlings Fed Fermented Groundnut Shell Diets}

The haematological parameters of fingerlings fed fermented groundnut shell diets are shown in Table 5 . The haematology sample collected at 12 weeks period showed that the results showed that all fish fed experimental diets were significantly different to each other. The highest value of packed cell volume (PCV), white blood cell (WBC), red blood cell (RBC), and haemoglobin $(\mathrm{Hb})$ were recorded in diet 5 with the corresponding value of $22.23 \%, 15.50 \times 10^{3}, 9.35 \times 10^{6}$ and $10.30 \mathrm{~g} / \mathrm{dL}$ respectively, while the lowest values were noted in diet 2 with $19.10 \%, 12.30 \times 10^{3}, 8.25 \times 10^{6}$ and $10.04 \mathrm{~g} / \mathrm{dL}$ respectively. The highest blood glucose of $43.29 \mathrm{mg} / \mathrm{dL}$ was recorded in diet 1 and $37.23 \mathrm{mg} / \mathrm{dL}$ was recorded in diet 3 as the lowest value.

\section{Discussion}

In this study, there was a general increase in weight gain in all treatments which indicated that the fish were able to convert feed protein to extra muscles. Weight gain and growth rate are usually considered as the most important measurement of productivity of diets [36,37]. The increased in weight gain recorded in all the treatments also indicated that the fish responded positively to all the diets and that the protein content of the fermented groundnut shell diet enhanced the growth of the fish. This observation is in agreement with the report of Fagbenro and Arowosoge [38] as well as Eyo and Olatunde [39]. Fish fed diet 5 had the highest mean weight gain $5.87 \mathrm{~g}$ and the least was recorded in fish fed $\operatorname{diet} 4(3.84 \mathrm{~g})$ respectively.

Specific growth rate (SGR) was highest $(0.51 \% /$ day) in diet 5 and the least $(0.38 \% /$ day) in the diet 4 . SGR values obtained for diet 1, 2, 3 and diet 5 were not statistically different but differed significantly from the values obtained for diet 4 and diet 1 . The best feed conversion ratio (FCR), 0.43 recorded for diet 5 is an indication of an optimum level of utilization of the groundnut shell diet by the Clarias gariepinus fingerlings. This corresponds with Adikwu [40] who stated that the lower the FCR, the better the feed utilization by the fish. In this study, the lowest FCR value is an indication of better feed utilization by the fish and this account for better growth performance of $C$. gariepinus fed diet 5 among other diets. This corresponds with observation made by Shabbir, et al. [41] and Jabeen, et al. [42] in related studies on feeding trials.

Protein efficiency ratio (PER) is known to be regulated by non-protein energy input of the diet and is a good measure of protein-sparing effect of lipid and/or carbohydrate $[43,44]$. PER recorded in this research work exhibited significant differences in all treatments. The significantly higher PER value obtained in diet 5 indicated maximum utilization of inherent nutrients in the diet at this level which was not in other diets. This does not agree with the observation made by Adejumo [45] who reported highest PER value at $20 \%$ inclusion level of replacing maize with fermented millet.

Net Protein Utilization (NPU) signifies protein retention in the body of the fish. This is a factor of the quality, digestibility and utilization of the protein fed to the fish. NPU of this study showed a significant difference between the diet 1 and the fermented groundnut shell diets 2, 3, 4, and 5 . Diet 5 recorded better NPU compared to diet 1 and other fermented diets. This observation agrees with the report of Sogbesan [46] who recorded highest value at $25 \%$ inclusion level of earthworm meal.

The general well-being of the fish fed fermented groundnut shell diets are expressed by the condition 


\section{International Journal of Oceanography \& Aquaculture}

factor $(\mathrm{K})$ which is significantly different from the diet 1. Survival rate was high in all treatments. The highest value (93\%) was recorded in diet 3 and least $(80 \%)$ was recorded in diet 5 . The mortality occur in this study might be due to the antinutrients present in the diets and some other extraneous factors which agreed with Alegbeleye [47] who reported that mortality might not be due to the antinutrients in the diets alone but also to some other extraneous factors such as stress resulting from handling.

The applications of haematological techniques have proved valuable for fishery biologists in assessing the health of fish and monitoring stress responses. Some of the values were fluctuating due to the condition under which the fishes were kept, the condition based on the fact that the fishes are not in their natural habitat and also because of sizes of the fishes, blood values such as the white blood cell, red blood cell and haemoglobin value as reported by Osuigwe, et al. [48] that the haematological parameters of fish are affected by a range of factor which includes size age, physiological status and environmental conditions and dietary regime (e.g quality and quantity of food dietary ingredients, protein sources, vitamins etc).

The haematology results of the present study showed that white blood cell (WBC) red blood cell (RBC), and packed cell volume (PCV) was affected by diet treatment. The positive effect of the experimental diets on the fish growth and physiology indicated that incorporation of fermented groundnut shell into the fish feed will not hampered both the development and health being of fish.

Generally, erythrocyte counts are used as indicators for anaemia. The erythrocyte counts obtained for diet C, S12, SA12, SA24 and SA48 were 9.10, 8.25, 9.22, 9.35 and $10.04 \times 10^{6} / \mu$ respectively and were comparable to those reported for Clarias gariepinus, but were higher than values of 1.33-1.77 reported for other African freshwater fishes [49]. Similarly, there was decline in red blood cell (RBC) value compared with the normal value $\left(24 \times 10^{6} / \mu\right)$ reported by Adedeji, et al. [50]. The reduced erythrocyte count may preclude the possibility of haemolytic anaemia stated by Kelly [51] who may be due to toxic factor, infections and metabolic diseases. Blaxhall and Daisley [52] noted that fish biologist rely more on haematocrit and haemoglobin concentration estimates as indicators of anaemia.

White blood cell counts are useful as indicators of disease condition or response to infection, and significantly elevated or depressed values are obtained in abnormal conditions. Similarly, it is a function of the immunity and this makes fish resistance to some vulnerable diseases. There is marked increase in the white blood cell (WBC) counts across the treatments compare with normal value $\left(6.6 \times 10^{6} / \mu\right)$ recommended by Adedeji, et al. [50]. Increase in WBC may be attributed to increase in production of leucocytes in the haemotopoietic tissue in the kidney and perhaps the spleen. The WBC count in this study is also significantly different and higher than the value $7.25 \mathrm{x}$ $10^{6} / \mathrm{mm}^{3}$ obtained by Fagbenro, et al. (1993)

Packed cell volume (PCV) values falls within the range of $20 \%$ and $35 \%$ as reported by Fagbenro, et al. [3,4] for freshwater fishes such as Clarias gariepinus, Clarias isheriensis, Heterobranchus longifilis and Heterobranchus bidorsalis. PCV is important as an indicator of the percentage of the packed red blood cells, and the colour of the plasma layer above the packed cells, and could be used to detect haemolysis [53]. There is therefore the possibility of using haematocrit as a tool in aquaculture and fisheries management for checking anaemic condition in fishes.

In fish blood, oxygen is carried in physical solution and also in combination with haemoglobin $[3,4]$. Haemoglobin is crucial for the survival of the fish as its role is directly related to the oxygen binding capacity of blood. The haemoglobin concentration values obtained in this study ranged between 10.04 and $10.55 \mathrm{~g} / \mathrm{dl}$. This is higher than the values of 7.44-8.66 $\mathrm{g} / \mathrm{dl}$ reported for estuarine catfishes, C. nigrodigitatus and C. furcatus [49,54], but were lower to the values of 11.64-15.43 g/dl reported for air breathing clarid catfishes, $C$. isheriensis, C. gariepinus, $H$. longifilis and $H$. bidorsalis $[49,55]$.

The mean corpuscular haemoglobin concentration (MCHC) values (46.33-52.57 g/dl) were significantly higher than the value $30-35 \mathrm{~g} / \mathrm{dl}$ recommended by Adedeji, et al. [50]. Similarly, in this study there are wide variations in both the mean corpuscular volume (MCV) and mean corpuscular haemoglobin $(\mathrm{MCH})$. And the lowest blood glucose was recorded in SA48, 33.33mg/dl and highest value of blood glucose $43.29 \mathrm{mg} / \mathrm{dl}$ in control diet.

\section{Conclusion}

The result of 12 weeks feeding trial of Clarias gariepinus with fermented groundnut shell diets showed that fermented groundnut shells could be used in fish production. However, growth performance and blood parameter could be improved in fish by incorporating 


\section{International Journal of Oceanography \& Aquaculture}

groundnut shells with potash fermented for 48 hours. It can be deduce from this research study that feed incorporated with fermented groundnut shells at 489 hours fermentation can be used as fish feed in catfish culture, to enhance fish health, survival, better feed efficiency and growth performance.

\section{References}

1. Bello OS, Olaifa FE, Emikpe BO, Ogunbanwo ST (2012) The effect of walnut (Tetracarpidium conophorum) leaf and onion (Allium cepa) bulb residues on the tissue bacteriological changes of Clarias gariepinus juveniles. Bulletin of Animal Health and Production in Africa 60(2): 205-212.

2. Rawling MD, Merrifield DL, Snellgrove DL, Kühlwein H, Adams A, et al. (2012) Haemato-immunological and growth response of mirror carp (Cyprinus carpio) fed a tropical earthworm meal in experimental diets. Fish \& Shellfish Immunology 32(6): 1002-1007.

3. Fagbenro OA, Smith MAK, Amoo AI (2000) Acha (Digitaria exilis stapf) meal compared with maize and sorghum meals as a dietary carbohydrate source for Nile Tilapia. The Israeli Journal of Aquaculture Bamidgeh 52(1): 3-10.

4. Fagbenro OA, Adedire CO, Ayotunde EO, Faminu EO (2000) Haematological profile, food composition and digestive enzyme assay in the gut of African bony tongue fish, Heterotis niloticus (Cuvier, 1829) (Osteoglossidae). Tropical Zoology 13(1): 1-9.

5. Babatunde GM, Fajimi OA, Oyejide OA (1992) Rubber seed oil versus palm oil in the broiler chicken diet. Effect of performance nutrient digestibility, haematology and carcass characteristics. Animal Feed Science Technology 35: 133-146.

6. Babatunde MM, Oludimiji AA, Balogunj K (2001) Acute toxicity of Gamaxone to Oreochromisniloticus (treweva) in Nigeria. Water Air soil pollution 13(1-4): 1-10.

7. Haruna AD, Adikwu II (2001) Haematological response to non-familiar diets. A study of Clariasgariepinus. Journal for Arid Zone Fishery 1: 1222.

8. Folmar O (1993) Haematological profile of Clariasgariepinus; particularly blood parameters.
Turkish Journal of Fisheries and Aquatic Sciences 7: 163-169.

9. Golovina NA (1996) Morpho-functional Characteristics of the Blood of Fish as Objects of Aquaculture. Ph.D Thesis, University of Moscow, Moscow.

10. Luskova V (1997) Annual Cycles and normal values of haematological parameters in fishes. Acta Sc Nat Brno 31(5): 70-78.

11. Lebedeva NE, Vosyliena VZ, Golovkina TV (1998) Haematological Biochemical responses of fish to biogenous and anthropogenic chemical stimuli ichthyohaematology. Proceedings of the $4^{\text {th }}$ Ichthyohematological conference, Hluboka/ Vit, Czech, pp: 85-87.

12. Rehulka J (2002a) Aeromonas causes severe skin lesions in rainbow trout (Oncorhynchusmykiss). Clinical Pathology, Haemology and Biochemistry Acta Vet Brno 71: 351-360.

13. Rehulka J (2002b) Effect of Polychlorinated biphenyls Delor 103 on some haematological and biochemical indices of the blood plasma of the rainbow trout. Oncorhynchusmykiss(Walbaum). In: The second PCB Workshop. Recent advances in the environmental toxicology and health effects of PCBS, Brno, Czch Republic (Book of Abstracts), pp: 36.

14. Rainza Paiva MJT, Ishikawa CM, Das Eiras AA, Felizardo NN (2000) Haematological analysis of chara, Pseudoplatystomafasciatum in captivity. Aqua 2000. Responsible aquaculture in the new millennium. European Aquaculture Soc Special Pub. Nice, France, pp: 590.

15. O'Neal CC, Weirich CR (2001) Effects of low level salinity on production and haematological parameters of channel catfish, Ictaluruspunctatus reared in multi-crop ponds. In Book of Abstracts, Aquaculture Int Triennal Conf of World Aquaculture Soc, Disney Colarado Springs Resort Lake Buna Vista, Florida, pp: 484.

16. Alu RJ, Adua MM, Thani RJ, Abubakar HT, Mathew UD (2012) Effect of different alkali-treated groundnut (Arachis hypogea) shell on blood parameters and meat yield of broiler finisher chickens. Journal of Agricultural Science 2(9): 224-230. 


\section{International Journal of Oceanography \& Aquaculture}

17. Sogbesan OA, Mohanta KN, Sahoo PK, Mitra G, Jayasankar P (2012) Maize Cob: A Reliable Co-energy source in Fish Feed. In: National Workshop on Application of Solid State Fermentation Technology in Aquaculture, pp: 118-128.

18. Sobamiwa O (1993) Use of Cocoa-Pod Husk in Poultry Feeds: A Particular Reference to

19. Osterli VP (1972) Panel: Agricultural Waste Disposal.

20. Westendorf ML (2000) Food waste to animal feed. Wiley- Blackwell, Oxford, pp: 86.

21. Maheswari DK, Vetriselvi J, Saravananmuthu R, Dhivaharam V, Dhiva S, et al. (2010) Industrial exploitation of microorganisms. IK International Pvt. Limited, New Delhi.

22. Lesdema RGG, Santos F, Briagas KB (2004) Spectrophotometric determination of phytic acid levels in plant feedstuffs for Get-Excel Tilapia feed formulation.

23. Felix JP, Mello D (2000) Farm Animal Metabolism and Nutrition. CABI, United Kingdom.

24. Panhwar F (2005) Antinutritional factors in oil seeds as aflatoxin in groundnut.

25. El-Sayed AFM (2004) Protein nutrition of farmed tilapia: searching for unconventioncal sources. In Proceedings 6th International Symposium on Tilapia in Aquaculture, Manila: Signa-Tala Publishing Incorporated, pp: 364-378.

26. Ebine H (1973) Integrated research on agricultural waste reclamation.

27. Tuah KA (1988) Utilization of Agricultural ByProducts for Village and Commercial Production of Sheep Rations in Ghana. Paper Presented at the First Joint Pasture Network for Eastern and Southern Africa/African Research Network for Agricultural ByProducts (PANESA/ARNAB) Workshop Held in Lilongwe, Malawi.

28. Ranjhan SK (1997) Animal Nutrition in the Tropics. $4^{\text {th }}$ (Edn.), Modern Printers, Delhi, pp: 59-99.

29. FAO/WHO (2011) Codex Alimentarius Commission procedural manual. 19th (Edn.), World Health Organization and Food and Agriculture Organization of the United Nations, Joint FAO/WHO Food Standards Programme, Rome.

30. Association of Official Analytical Chemists (2010) Official methods of chemical Analysis. 17th (Edn.), Washington DC, USA.

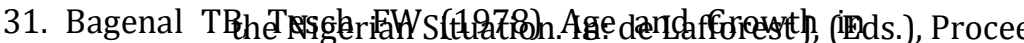
Methods of assessment of fish production on freshwater. Blackwell Scientific Publication Oxford, IBP Handbook No 3, pp: 101-136.

32. Fasakin EA, Balogun AM, Edomwagogbon O (2004) Aspects of chemical and biological evaluation of dried maggot meals in production diets for Clarid Catfish, Clarias gariepinus. World Journal of Biotechnology 5: 753-762.

33. Wilson RP (1989) Protein and amino acid requirements of fishes. In: Shiau S, (Ed.), Progress in Fish Nutrition, National Taiwan Ocean University, Keelung, Taiwan, pp: 51-76.

34. Steffens W (1989) Protein utlizatio by Rainbow trout (Salmo gardineri) and Carp (Cyprinus carpio): A brief review. Aquaculture 23(1-4): 337-345.

35. Schalm OW, Jain NC, Caroll EJ (1975) Textbook of Veterinary Haematology, 2nd Edition, Published by Lea and Febiger, Philadelphia, pp: 129-250.

36. Hossain MA, Nahar N, Kamal M, Islam MN (1995) Nutrient digestibility coefficients of some plant and animal proteins for tilapia (Oreochromis mossambicus). Journal Aquaculture in the Tropics 7: 257-266.

37. Omitoyin BO, Faturoti EO (2000) Effect of raw and parboiled chicken offal in the diet of Clarias gariepinus. Aquabyte 1: 20-25.

38. Fagbenro AO, Arowosoge IA (1991) Replacement values of some household wastes as energy substitutes in low-cost diets for rearing catfish in south-western Nigeria. Bioresource Technology 37(3): 197-203.

39. Eyo AA, Olatunde OA (2001) Protein and amino acid requirements of fish with particular reference to species cultured in Nigeria. In: Fish Nutrition and Fish Feed Technology (A.A. Eyo, Eds), Fisheries Society of Nigeria, Lagos, pp: 59-74. 


\section{International Journal of Oceanography \& Aquaculture}

40. Adikwu IA (2003) A Review of aquaculture: Nutrition in aquaculture development in Nigeria. In Proceeding of the Joint Fisheries Society of Nigeria, National Institute for Freshwater Fisheries Research, FAONational special programme for food security National Workshop on Fish Feed Development and feeding practices in Aquaculture held at National Institute for Freshwater Fisheries Research, NewBussa, pp: 34-42.

41. Shabbir S, Salim M, Rashid M (2003) Study on the feed conversion ratio (FCR) in major carp (Cirrhinus mrigala) fed on sunflower meal, wheat bran and maize gluten (30\%). Pakistan Veterinary Journal 23(1): 1-3.

42. Jabeen S, Salim M, Akhtar P (2004) Study on feed conversion ratio of major carp (Cirrhinus mrigala) fingerlings fed on cotton seed meal, fish meal and barley. Pakistan Veterinary Journal 24(1): 42-46.

43. Li O, Lied E, Lamberaton G (1989) Haematological values and fatty acid composition of erythrocyte phospholipids in cod (Gadus morhua) fed at different water temperatures. Aquaculture 79: 137-144.

44. Tibbets SM, Lall SP, Milley JE (2005) Effect of dietary protein and lipid levels and dietary protein/dietary energy ratio on growth, feed utilization and hepatosomatic index of juvenile haddock, Melanogramms aeglefonus. Aquaculture Nutrition 11(1): 67-78.

45. Adejumo OK (2005) Haematological and Histopathological effects of cassava mill effluentin Clarias gariepinus. African Journal of Biomedical Research 8: 179-183.

46. Sogbesan OA (2007) Culture and Utilization of some non-conventional animal feedstuffs in the diet of Heterobranchus longifilis. PhD Thesis University of Ibadan, Ibadan, pp: 266.
47. Alegbeleye WAO (2005) Growth performance and haematological profiles of Oreochromis niloticus fingerlings fed differently processed cotton seed meal. Ph.D Thesis, Department of Zoology, University of Ibadan, Ibadan, pp: 213.

48. Osuigwe DI, Obiekezie AI, Onuoha GC (2005) Some haematological changes in hybrid catfish (Heterobranchus longifilis $x$ Clarias gariepinus) fed different dietary levels of raw and boiled jackbean (Carnavalia ensiformis) seed meal. African Journal of Biotechnology 4(9): 1017-1021.

49. Erondu ES, Nubian C, Nwaduke O (1993) Haematological studies on four catfish species raised in freshwater ponds in Nigeria. Journal of Apllied Ichthyology 9(3-4): 250-256.

50. Adedeji OB, Taiwo 0, Agbede SA (2000) Comparative Haematology of five Nigerian freshwater fish species. Nigeria Veterinary Journal 21: 75-84.

51. Kelly WR (1974) Veterinary Clinical Diagnosis. $2^{\text {nd }}$ Edition Macmillan Publisher, London, pp: 204-294.

52. Blaxhall PC, Daisley KW (1973) Routine haematology methods for use with fish blood. Journal of Fish biology 5(6): 771-781.

53. Archer RK, Jeffcott LB (1977) The haematological assessment of the health of freshwater fish. A review of selected literature. Journal of Fish Biology 4: 593604.

54. Etim L, Ekanem SB, Utin A (1999) Haematological profile of two species of catfish, Chrisichthys nigrodigitalis (Lacepede) and Chrisichthys furcatus (Gunther) from the Great Kwa river, Nigeria. Global Journal of Pure and Applied Sciences 5: 1-4.

55. Kori-Siakpere O (1985) Haematological characteristics of Clarias isheriensis Sydenham. Journal of Fish Biology 27(3): 259-263. 